\title{
The Influence of Corporate Governance and Intellectual Capital towards Financial Distress (Empirical Study of Manufacturing Company in IDX for the Period of 2014-2016)
}

\author{
Muhammad Rasil Fashhan \\ rafashhan29@gmail.com \\ Accounting Study Program, Faculty of Business \\ Universitas Presiden, Cikarang, Indonesia \\ Vita Elisa Fitriana \\ vita.elisa@president.ac.id \\ Accounting Study Program, Faculty of Business \\ Universitas Presiden, Cikarang, Indonesia
}

\begin{abstract}
This study aims to test and find empirical evidence on the effects of corporate governance and intellectual capital on financial distress. In this study, the data sample used are manufacturing companies that publish their financial reporting in rupiah currency and listed in Indonesia Stock Exchange. Data collection method using purposive sampling and collected 249 samples from 2014-2016. The method of analysis used in this study is multiple regression analysis. The results of this study indicate that corporate governance does not have a significant effect on the financial distress of the company. While the relationship between intellectual capital and financial distress of the company showed a significant positive effect.
\end{abstract}

Keywords: Corporate Governance, Intellectual Capital, Financial Distress

\begin{abstract}
Abstrak
Penelitian ini bertujuan untuk menguji secara empiris pengaruh tata kelola perusahaan dan modal intelektual terhadap kesulitan keuangan. Dalam penelitian ini, sampel yang digunakan berupa perusahaan manufaktur yang menerbitkan laporan keuangan dalam satuan mata uang rupiah dan terdaftar dalam Bursa Efek Indonesia. Pengumpulan data menggunakan metode purposive. Hasil seleksi sampel memperoleh 249 sampel dari tahun 2014-2016. Metode analisis data menggunakan analisis regresi linier berganda. Hasil pengujian menunjukkan bahwa tata kelola perusahaan tidak berpengaruh signifikan terhadap kesulitan keuangan. Di sisi lain, modal intelektual berpengaruh positif signifikan pada kesulitan keuangan.
\end{abstract}

Kata kunci: Tata Kelola Perusahaan, Modal Intelektual, Kesulitan Keuangan 


\section{INTRODUCTION}

The existence of businesses in the market is keep on increasing, which results in high competition. Based on data from www.sahamok.com the growing number of business is not only for service industry, it also applied in manufacturing companies. Manufacturing companies are a branch of industries, which combines the use of machines, equipment and employee in a process to convert raw materials into finish good (Kerfai, et al., 2016). Manufacturing companies in Indonesia are developing from year to year. It can be seen from the number of manufacturing companies established in Indonesia, which shows that out of 132 companies in 2012, it is growing on 2016, which is up to 144 companies (SahamOK, 2017). From the growth of manufacturing companies until now, lots of companies are not able to continue their operations due to lots of competitors among them. However, the reason they discontinue their operations can also happen due to the internal management of the company itself, for example they are not able to maintain their financial aspect, which results in bankruptcy.

Lee and Yeh (2004) mentioned that financial distress is the company's inability to pay their financial obligation at maturity which could happen the company will be bankrupt and financial distress can lead to bankruptcy, liquidation or significant changes in management control. The way to reduce the risk is by lowering the debt of the company (Friend and Lang, 1988). Relationship managers with shareholders in agency theory describes as the relationship between agent and principal (Brailsford et al., 1999). According to Jensen and Meckling (1976), agency theory views the management of the company as an agent for shareholders, who will act with full awareness for its own interest, not as a wise and fair for shareholders. Managers should take the business decisions to increase shareholder wealth.

Haat et al., (2011) explained that when a company failed in their financial aspects. It indicates that the company has poor corporate governance. If the company's financial condition is not good, it will generate some problems that will be complicated for the company. Those things happen because the company would lose customers and suppliers. Not only that, the most important thing is that they will lose their investor because action done by the company that only focus on their financial difficulties rather on their business development. When companies are having financial difficulties, there are possibilities that they are not able to pay their liabilities, which shows a condition of financial distress. It is said that the existence of financial distress at the company can cause problem that can reduce the efficiency of management.

Besides corporate governance, Smedlund and Polyhonen (2005) explains that intellectual capital is a capability or the ability of the organization to create, transfer knowledge and then apply that knowledge. Intellectual capital is one of the important capital component to conduct the activities that can be used to create new innovations in utilizing the existing resources and then apply the result of creation and such development. The company can have good financial performance if they have a creative idea, flagship programs, human resources, organizational structure and good relationship with stakeholder. To get the expected profit, each company must carry out efficiency in order to maintain the continuity of efforts or improving competitiveness.

This study has a purpose to find out the relationship between corporate governance and intellectual capital towards financial distress. A research done by Shahwan (2015) explains about the effects of corporate governance on financial performance and financial distress. There is an insignificant relationship between corporate governance practices and the likelihood of financial distress. According to Shahwan (2015), the result does not significant because the company in Egypt not totally implement corporate governance. That matter becomes the motivation to do the research in Indonesia, because companies in Indonesia have 
implemented corporate governance practices based on regulatory Otoritas Jasa Keuangan (OJK) No. 21 / POJK.04 / 2015 about the guideline of corporate governance implementation in public company. Besides that, Shahwan (2015) also stated that the testing should be related to financial performance and financial distress with intellectual capital as variable.

In Australia, Clarke et al., (2011) did a research about the relationship between intellectual capital and financial performance. The result shows that intellectual capital has a direct relationship towards financial performance. All components of intellectual capital, such as human capital efficiency (HCE), structural capital efficiency (SCE) and capital employee efficiency (CEE). From the results, it shows that all component of intellectual capital has a positive relationship towards financial performance.

\section{LITERATURE REVIEW}

\section{Agency Theory}

A research done by Jensen and Meckling (1976) discuss about the connection between agent and principal. Agent is the management of the company, while principal is the owner of the company. The principal is the party that gives the agent the mandate to act on behalf of the principal, while the agent is the party who is mandated by the principal to run the company. Therefore, the agent has more information about the company than the principal. This information inequality is commonly referred to as information asymmetry (Jensen and Meckling, 1976).

Information asymmetry occurs because the agent has more complete information on the actual internal condition of the company and the future prospects of the company than the principal. Both principals and agents have different economic interests and seek to maximize them. Principals want the maximum profit or increase the value of investment in the company, while the agent wants adequate compensation for the performance performed (Sari, 2012). The agent may be afraid to disclose information that the owner does not expect, so there is a tendency to manipulate the financial statements.

The existence of information asymmetry raises two problems caused by the principal difficulty to monitor and control the actions of agents. According to Jensen and Meckling (1976) the problem is:

a. Moral Hazard, a problem that arises because of a conflict of interest between the agent and the principal that may lead to the act of cheating or fraud agent to the principal.

b. Adverse Selection, a condition where the agent is much more aware of the actual condition of the company and its prospects in the future than the principal, thus causing investment decision choices that are detrimental to the principal.

Therefore, an independent third party is required, in this case a public accountant. Auditors play a role in bridging the interests of managers and owners of the company. The auditor also serves to monitor the behavior of the manager (agent) whether it has acted in accordance with the wishes of the principal (Jensen and Meckling, 1976). In this case the auditor gives an opinion on the reasonableness of the company's financial statements and disclose the issue of going concern faced by the company if the auditor doubts the company's ability to maintain its survival (Kabir and Rahman, 2016).

Corporate governance develops with dependence on agency theory, where the management of the company should be supervised and controlled to ensure that management is carried out in full compliance with applicable rules and regulations (OECD, 2004). These efforts then incur agency costs. These agency costs include supervisory fees by shareholders, management costs incurred to produce transparent reports, including independent audit fees 
and internal controls, as well as costs due to impairment of shareholder value (OECD, 2004).

\section{Corporate Governance}

Agency relationship is defined as a contractual agreement between one or more persons of the principal with another party who is called the agent to do something for the interest of the principal by Jensen and Meckling (1976). They assume the agent will not always do the best for the principal's interest but the agent does the best for the agent's own interest. In this case, there is an unconformity between the interests of the owner and manager so that will cause agency problem. Eisenhardt (1989) using three basic human assumptions to explain the theory of the agency: (1) human beings are selfish, (2) human beings have limited thinking about future perceptions, and (3) human always avoid risk. Solution to reduce agency problem is to apply good corporate governance (GCG) practice in a company (Jensen and Meckling, 1979).

The word governance comes from the French language is gubernance which means control. The word is used in the context of corporate or organizational activities into corporate governance (Sutojo and Aldridge, 2008). Some concepts of corporate governance include those proposed by Shleifer and Vishny (1997) which states that corporate governance deals with ways or mechanisms to convince the owners of capital in obtaining returns that match the investments that have been invested. Iskander and Chamlou (2000) states that corporate governance refers to a framework of rules and regulations that allow stakeholders to make companies maximize value and to earn returns.

According to IICG (Indonesian Institute of Corporate Governance), corporate governance is a system used by parts of the company to obtain added value that can provide benefits to the company in the long term. According to the regulatory Otoritas Jasa Keuangan (OJK) No. 21 / POJK.04 / 2015, corporate governance is a process undertaken by the company to achieve success in the business undertaken by the company. So, it can be concluded that corporate governance is a system that can manage and control the activities of the company in order to improve and promote the productivity of the company, thereby increasing the value of the company that in the long term will increase the value of stocks and added value for stakeholders.

The benefits of GCG are enhancing the reputation of management, facilitating business risk management, enhancing creativity and delivery, improving operational efficiency with cost savings and according to the capital market body in many countries stating that GCG prevents the disclosure of non-transparent financial statements, guidance to the management of the company effectively thereby increasing the value of the company (Sutojo and Aldrige, 2008). Dwiridotjahjono (2009) mentions the benefits of implementing corporate governance are: (1) Improve productivity efficiency; (2) Increasing public confidence; (3) Maintaining the survival of the company; (4) Measure company performance targets.

The implementation of GCG can improve the company's performance, by improving financial performance, reducing the risks that the board may have with favorable decisions, and generally corporate governance can increase investor confidence. Poor corporate governance lowers investor confidence, weak GCG practice is one of the factors that prolong the economic crisis in the state of Indonesia Dwiridotjahjono (2009).

In general, corporate governance arises in an attempt to control self-interested management behavior by creating control tools to enable a balanced profit-sharing system for investors and stakeholders, while also improving investor confidence. Good Corporate Governance (GCG) is one of the key to success of the company to grow and benefit in the long run, while winning global business competition (Kaihatu, 2006). So, with the system of good corporate governance applied in the company, it is unlikely that the company has financial difficulties (financial distressed) that will lead to bankruptcy. The fate of the 
company, whether to succeed or fail is usually based on the strategy used by the company (Porter, 1991). There are 2 kinds of characteristics that can determined the success of the company, such as strategic and managerial characteristics. These strategies may also include strategies for implementing the Good Corporate Governance (GCG) system within the company. GCG structure in a company may be able to determine the success or failure of a company.

According to Shahwan (2015), corporate government index (CGI) is the measurement used to assess the quality of corporate governance practices of companies in Indonesian Stock Exchange. CGI consists of 4 categories, such as: (1) disclosure and transparency; (2) characteristics of directors; (3) the rights of shareholders and relations with investors; and (4) ownership and control structure. Moreover, CGI consist of 15 questions, which includes 3 questions of category 1, 6 questions of category 2, 2 questions about category 3 , and 4 questions of category 4 . Those questions about corporate governance will be answered by seeing the data of the company in annual report.

The use of publicly available secondary data eliminates the risk of third-party responses. By adopting an unweighted corporate governance index, each index question generates a score of " 1 " if the answer is "YES" and " 0 " otherwise. The total corporate governance index value for each company can be defined as follows:

$$
C G I_{J}=\frac{\sum_{i=1}^{n} X_{i j}}{\sum_{i=1}^{n} M_{i}}
$$

\section{CGI : corporate governance index}

$M_{i} \quad$ : the maximum score given to the company for all categories $(i=1, \ldots, 4)$.

$X_{i, j} \quad$ : reflects the actual score attained by each firm.

To ensure the quality of corporate governance index, the results of CGI should be stable and consistent. Following Samaha et al. (2012), to get the reliable index, everything should be read and counted twice, in order to achieve the same score and the value of $(\alpha \geq 0.70)$ indicates a good reliability.

\section{Intellectual Capital}

According to Brooking (1996), intellectual capital (IC) is an intangible asset that allows the companies to run. The intangible assets include the market, human, infrastructure, and intellectual property. However, Roos et al. (1997) states that intellectual capital is the assets that are not included in balance sheet, for example trademarks, patents and brands.

Intellectual capital is a difficult thing to be understood. However, if the company is able to discover it, it can become the competitive advantage for the company in the market (Bontis, 1998). The Organization for Economic Cooperation and Development (OECD, 1999) describes intellectual capital as the economic value of two categories of intangible assets, such as organizational capital and human capital. Organizational capital can also be stated as structural capital. The examples of organizational capital are software systems, distribution networks, and supply chains. However, human capital is the human resources in the company. For instance, the employees, consumers and suppliers (Ulum, 2008).

Based on Stewart (1998), there are 3 main elements of intellectual capital, such as:

a. Human Capital Human capital is one of the most important intellectual capitals inside an organization. This capital is the source of knowledge, skills and competencies in an organization. Those sources can be used by the organization to make some 
improvements and innovation. Human capital reflects the ability of a company to produce the best solution based on the sources acquired by the people inside the company. When the company is able to use the sources from the employees, the human capital will increase.

b. Structural Capital Structural capital is the ability of the organization in fulfilling the process in the company that can also supports the employees to achieve optimal intellectual performance and also the company performance itself. An individual can have a high level of intellectuality, but if the organization is lack of management, systems and procedures, then optimal performance cannot be achieved by intellectual capital. c. Relational Capital

c. Relational capital is relationship that the company has with its partners. The relationship can be between the company with its reliable suppliers, loyal customers, government and local communities. Relational capital can also from outside the environment of the company and it can add value to the company.

Intellectual capital can be measured by value added intellectual coefficient (VAIC). It includes 3 components, such as human capital efficiency (HCE), structural capital efficiency (SCE), and capital employed efficiency (CEE) (Chen et al., 2005). VAIC measures the level of intellectual capital and provide information of how efficient the company valued its tangible and intangible assets (Tan et al., 2007).

$$
\mathrm{VAIC}=\mathrm{HCE}+\mathrm{SCE}+\mathrm{CEE}
$$

Value Added (VA) is the difference between sales (OUT) and input (IN). The formula for calculating VA is:

S : Net Sales Revenue (Output)

$$
\mathbf{V A}=\mathbf{S}-\mathbf{B}
$$

$\mathrm{B}:$ COGS (Input)

Each component of VAIC has its own calculation. Here are the explanations:

a. Human capital (HC) refers to the source of knowledge, skills and competencies in an organization (Pulic, 1998). The formula for calculating HCE is:

$$
\mathrm{HCE}=\mathrm{VA} / \mathrm{HC}
$$

HC: Salary and employee benefits

b. Structural Capital (SC) is the ability of the organization in fulfilling the process in the company that can also supports the employees to achieve optimal intellectual performance and also the company performance itself. The formula for calculating SCE is:

$$
\begin{aligned}
& \text { SCE = SC / VA } \\
& \text { SC = VA }- \text { HC }
\end{aligned}
$$

c. Capital Employee (CE) is defined as the total capital utilized in the non-current asset and current assets of a company (Pulic, 1998). The formula for calculating CEE is:

\section{$\mathrm{CEE}=\mathrm{VA} / \mathrm{CE}$}

CE: Total assets 


\section{Financial Distress}

Financial distress is a condition where companies face difficulties in terms of financial condition. According to Platt and Platt (2002), financial distress is the stage of the company when they face a decline in their financial conditions. It usually happened because the company is not able to pay the obligations that have matured.

Elloumi and Gueyie (2001) considered companies that have financial distress if the company experienced net loss for two consecutive years. However, Classens et al., (1999) argued that companies in financial difficulty are when the interest coverage ratio is less than one. Moreover, Almilia and Kristijadi (2003) have the same statement with Elloumi and Gueyie (2001) that companies that have financial distress is when they have net loss and are not able to pay dividends to its shareholders.

Financial distress occurs when the company is experiencing financial difficulties that can be caused by various consequences. One of the causes of financial difficulties according to Brigham and Daves (2003) is the existence of a series of errors that occur within the company, poor decision making by managers, and interrelated weaknesses that can contribute directly or indirectly to company management, as well as other causes is the lack of monitoring efforts to the financial condition so that the use of corporate funds is less in accordance with what is needed. This leads to the conclusion that there is no guarantee that big companies can avoid this problem; the reason is that financial distress is related to the company's financial condition where every company will definitely deal with the finances to achieve the company's profit and survival targets.

The measurement to measure financial distress is Altman Z-score. The results of Altman Z-score shows that if the value is low, it means that there is a possibility that the company will go bankrupt. The company with Z-score value over 2.67 is considered healthy, while less than 1.81 indicates bankruptcy possibility. However, if the value is in between 1.81 and 2.67, it means that the company is in gray areas. The formula based on Altman (1968) can be calculated as follows:

$$
\begin{aligned}
& \mathrm{Z}-\text { Score }=1.2 \mathrm{X}_{1}+1.4 \mathrm{X}_{2}+3.3 \mathrm{X}_{3}+0.6 \mathrm{X}_{4}+1.0 \mathrm{X}_{5} \\
& \text { Where } \\
& \mathrm{X}_{1}=\text { Working Capital/Total Assets } \\
& \mathrm{X}_{2}=\text { Retained Earning/Total Assets } \\
& \mathrm{X}_{3}=\text { Earnings before Interest and Taxes/Total Assets } \\
& \mathrm{X}_{4}=\text { Market Value Equity/Book Value of Total Debt } \\
& \mathrm{X}_{5}=\text { Sales/Total Assets }
\end{aligned}
$$

\section{Hypothesis Development}

The agency relationship is a relationship between the principal and agent. The conflict of interest between principal and agent occurs when the principal is difficult to ensure the welfare of the principal, leading to agency costs as described by Jensen and Meckling (1976). The agency theory assumes that independent commissioners are required on the board of commissioners to supervise and control the actions of directors, in connection with their opportunistic behavior (Jensen and Meckling, 1976). Monitoring conducted by independent or external commissioners is considered capable of solving agency problems (Fama and Jensen, 1983).

Agency problems occur when managers tend to make decisions that benefit themselves rather than the interests of shareholders (Jensen and Meckling, 1976). Agency problem can harm the company's financial condition because it forces the owner to issue a number of costs called agency cost. The existence of a function of independent commissioners in overseeing the performance of the board of directors in terms of controlling the financial problems in 
order to avoid an action that could harm the company, it can make an independent commissioner plays an important role so that companies can avoid financial distress.

Research conducted by Huang and Zhao (2008) states that corporate governance affects the company's financial distress. Agency theory can be affected by the ownership structure resulting in conflicts between agents and principals. Corporate governance mechanism aims to create added value for all parties concerned so that there is no conflict between the agents and principals that give impact on the smooth performance of the company and can avoid the possibility of financial distress Based on the description above, the first hypothesis in this study are:

Hypothesis 1: There is an influence of corporate governance on financial distress.

Intellectual capital is an intangible asset that companies have that can help them to increase the competitive advantage and those intangible assets will contribute to the financial performance of the company (Harrison and Sullivan, 2000). By using VAIC formulated by Pulic (1998) as a measure of corporate intellectual abilities, intellectual capital could affect financial performance, the higher the intellectual capital, the better the financial performance. Therefore, it is possible to avoid financial distress.

Intellectual capital is influential with company performance data of the same year. Contemporary influences indicate the relevance of information to investors (Tan et al., 2007). If the information has been priced, then its value will be minimal to the investor. Corporate value and financial performance is can be improved by the role of intellectual capital in the company. Firer and Williams (2003), Chen et al., (2005) and Tan et al,. (2007) has proven that IC (VAIC) has a positive influence on the company's financial performance.

Good management of human resources in the company, employee productivity will increase. With the increase of employee productivity, it is expected to increase the profit of the company, which culminate later to the company's performance is considered good by the stakeholders. While on the contrary if the management of intellectual capital in the company is not managed properly then it will result in the performance of the company itself is considered not good / decreased. Decline in corporate performance will have an impact on the occurrence of financial distress. Based on the description above, the second hypothesis in this study are:

Hypothesis 2: There is an influence of intellectual capital on financial distress.

\section{Theoretical Framework}

To facilitate understanding between variables, the following figure shows the model of the research.

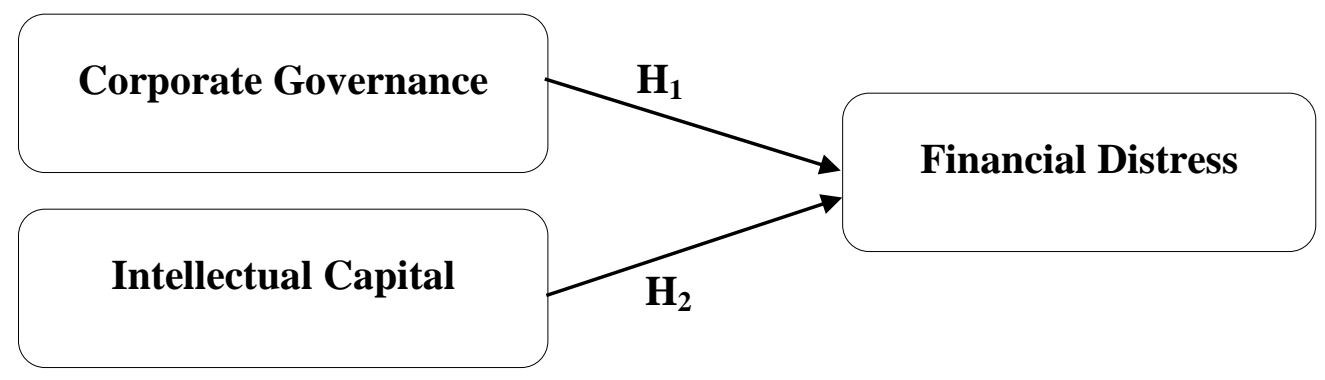

Figure 1. Theoretical Frameworks 


\section{RESEARCH METHOD}

This study uses a quantitative approach that uses inductive, objective, and specific nature whereas the data collected will be in the numerical data. The researcher used Statistical Package for the Social Sciences (SPSS) to test the hypothesis. This study uses the attributes of corporate governance, intellectual capital and financial distress in companies listed on the Indonesia Stock Exchange period 2014-2016.

The population in this study is a manufacturing company listed in Indonesia Stock Exchange (IDX) in 2014-2016 to predict the condition of financial distress based on corporate governance and intellectual capital. Methods of collection or selection of samples is purposive sampling. Purposive sampling is use to set specific criteria in the selection. This study used purposive sampling technique with the existence of special criteria such as:

1. Manufacturing companies listed in IDX in the period of 2014-2016, because manufacturing companies are the dominant companies in IDX.

2. The company reports the financial condition in rupiah currency because the exchange rate of another currency may change at any time against rupiah.

3. Have complete data for both variables, namely corporate governance and intellectual capital.

The type of data used in this study is quantitative. While the data collection method used is secondary data. This study used documentation method that is by doing data collection conducted by studying financial information, non-financial and other information published by companies or other parties. The data used are secondary data in the form of annual financial statements of companies listed on the Indonesia Stock Exchange (IDX).

The analysis model used is multiple linier regression analysis model. This model is used to determine the influence or influence of independent variables on the dependent variable which is bound by this equation.

$$
\text { Financial Distress }=\beta_{0}+\beta_{1} \text { Corporate Governance }+\beta_{2} \text { Intellectual Capital }+e
$$

B0: Constant

e: Error

\section{RESULTS AND DISCUSSION}

This study uses a sample of manufacturing companies listed in IDX starting 2014-2016 selected by purposive sampling method. The number of samples of 83 companies with observation data as much as 249. This study analyzed 2 independent variables using secondary data in the form of panel data.

\section{Descriptive Analysis}

Table 1. Descriptive Statistics

\begin{tabular}{lccccc}
\hline & N & Minimum & Maximum & Mean & $\begin{array}{c}\text { Std. } \\
\text { Deviation }\end{array}$ \\
\hline $\begin{array}{l}\text { Corporate } \\
\text { Governance }\end{array}$ & 249 & 0.33 & 0.80 & 0.58 & 0.09 \\
\hline Financial Distress & 249 & -129.16 & 1126.39 & 29.66 & 133.25 \\
\hline Intellectual Capital & 249 & 0.19 & 577.37 & 10.01 & 45.92 \\
\hline
\end{tabular}


Based on table above, the minimum, maximum, mean, and standard deviation value of each sample are explained below:

1. The minimum value of corporate governance is 0.33 that obtained from 4 manufacturing samples: PT Sepatu Bata Tbk in year 2014, PT Inter Delta Tbk in year 2014, PT Bentoel International Investama Tbk in year 2014, PT Bentoel International Investama Tbk in year 2015 and PT Tempo Scan Pacific Tbk in year 2015. The maximum value of CGI is 0.80 that obtained from 2 manufacturing sample: PT Dwi Aneka Jaya Kemasindo Tbk in year 2016 and PT Argha Karya Prima Industry Tbk in year 2016. The average value of corporate governance is 0.58 with the standard deviation value is 0.09 , which means that the mean value is greater than the standard deviation, thus indicating that the results are quite good. This is because the standard deviation is a reflection of a very high deviation, so the spread of data shows normal results and does not cause bias. The range of the corporate governance is between 0.33 until 0.80 with a standard deviation of 0.09 . It implies that there is little variation in practicing corporate governance mechanism. However, the mean value of the corporate governance is 0.58 . This implies that practicing corporate governance attributes is clearly weak despite significant efforts taken by authorities.

2. The minimum value of financial distress is -129.16 came from PT Dwi Aneka Jaya Kemasindo Tbk in year 2016, the maximum value is 1126.39 came from PT Inti Agri Resources Tbk in year 2015. The average value of financial distress is 29.66 with the standard deviation value is 133.25 . This means that the mean value is smaller than the standard deviation, thus indicating that the results are not good. Because the standard deviation is a reflection of a very high deviation, so the distribution of data shows abnormal results and causes bias. It was reflected that the mean of Altman Z-Score as a proxy for financial distress above 2.67 and interpreted as "Safe Zones" for bankruptcy.

3. The minimum value of IC came from PT Akbar Indo Makmur Stimec Tbk in year 2015 with the value of 0.19, the maximum value came from PT Unilever Indonesia Tbk in year 2016. The average value of intellectual capital is 10.01 with the standard deviation value is 45.92. This means that the mean value is smaller than the standard deviation, thus indicating that the results are not good. Because the standard deviation is a reflection of a very high deviation, so the distribution of data shows abnormal results and causes bias. According to Kamath (2007), a company will enter the top performance group if it has a VAIC score above 5.00. If the score is between 4.00 to 5.00, then it is in the category of good performance, and the common performance category for those who score between 2.5 to 4.00. While companies with VAIC scores below 2.5 are in the category of bad performance. In general, intellectual capital performance calculated with VAIC proxies is in the top performance category, if we see from the mean value of 10.01 .

\section{Classic Assumption Test}

In order that the regression model used in this study theoretically yields the appropriate parametric value, the data must need to past four classical assumption tests. Test the classical assumptions that have been made and the results are as follows: 
Normality Test

Table 2. One-Sample Kolmogorov-Smirnov Test

\begin{tabular}{ll}
\hline & $\begin{array}{l}\text { Unstandardized } \\
\text { Residual }\end{array}$ \\
\hline Significant Value & 0.651 \\
\hline
\end{tabular}

The result of normality test with Kolmogorov-Smirnov shows that the significant value at 0.651 . This means that the residual data is normally distributed and the regression model is proper for regression analysis.

Multicollinearity Test

Table 3. Collinearity Statistics

\begin{tabular}{llc}
\hline \multicolumn{1}{c}{ Model } & \multicolumn{2}{c}{ Collinearity Statistics } \\
\cline { 2 - 3 } & Tolerance & VIF \\
\hline $\begin{array}{l}\text { Corporate } \\
\text { Governance }\end{array}$ & 0.971 & 1.03 \\
\hline Intellectual Capital & 0.971 & 1.03
\end{tabular}

From the output above, independent variables have a tolerance value of each more than 0.10 and VIF value of each no more than 10. Therefore, it can be concluded that between independent variables there is no multicollinearity.

Heteroscedasticity Test

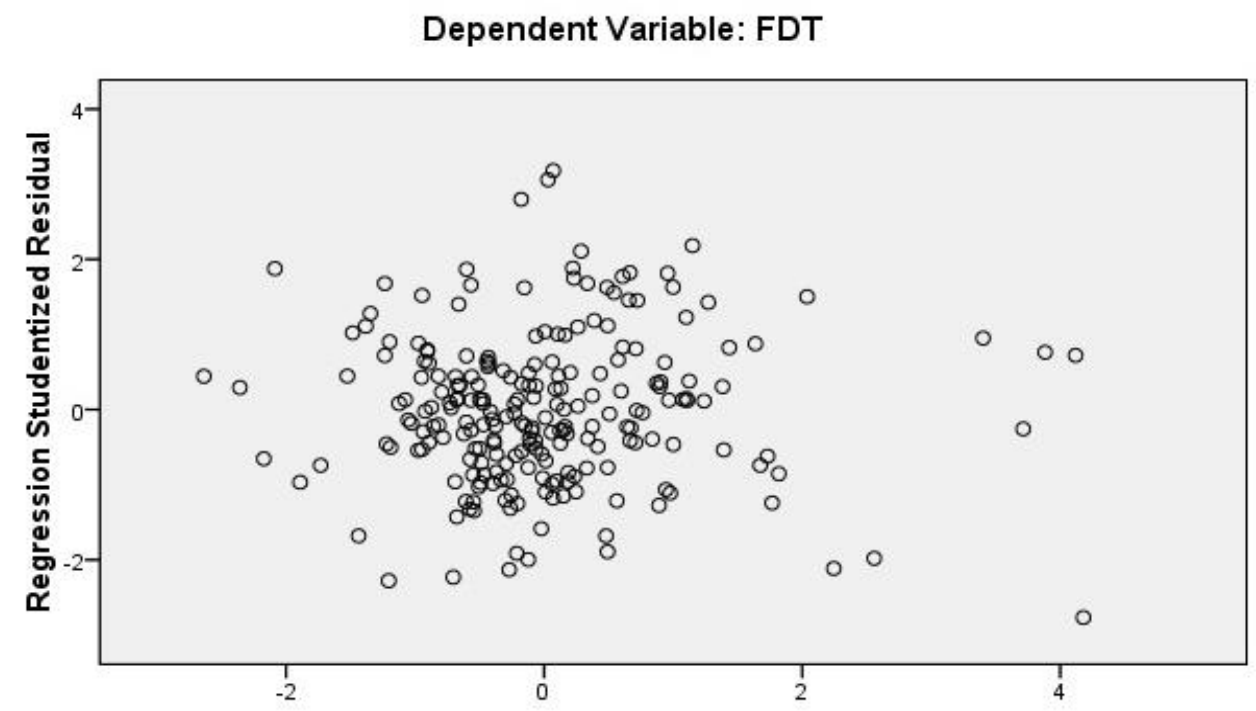

Figure 2. Scatterplot Test Model

Based on the diagram above, it appears that the point is spreading and does not form a certain clear pattern. Therefore, there is no heteroscedasticity. 
Autocorrelation Test

Table 4. Durbin-Watson

Model Durbin-Watson

$1 \quad 2.300$

The autocorrelation test in this research was conducted by using Durbin Watson test. The result of this test can be seen that the value of Durbin Watson is 2,300 with du 1.80887, and 4-du 2.19113. This Durbin Watson value is not between du and 4-du $(1.8>2.3<2.1)$. Thus, the regression model has an autocorrelation problem. Autocorrelation problems can be solved by running the Wald-Wolfowitz trial or simply known as the run test.

Table 5. Run Test

\begin{tabular}{ll}
\hline & $\begin{array}{r}\text { Unstandardized } \\
\text { Residual }\end{array}$ \\
\hline Significant Value & 0.062
\end{tabular}

From the run test, the significance value is 0.062 , which is higher than 0.05 and it can be summarized that the problem of autocorrelation has been solved.

\section{Hypothesis Test}

Coefficient Determinant $\left(R^{2}\right)$

Table 6. Coefficient Determinant $\left(\mathrm{R}^{2}\right)$

\begin{tabular}{lc}
\hline Indicator & Value \\
\hline $\mathbf{R}^{\mathbf{2}}$ & 0.094 \\
\hline Adjusted $\mathbf{R}^{\mathbf{2}}$ & 0.086 \\
\hline
\end{tabular}

From the above result, the value of Adjusted R Square (R2) is 0.086. This means that $8.6 \%$ of financial distress variables can be explained by independent variables are corporate governance and intellectual capital. While the remaining $91.4 \%$ can be explained by other factors.

F Test

Table 7. Result of F Test

\begin{tabular}{lll}
\hline Model & F Test & Sig. \\
\hline Regression & 11.557 & 0.000 \\
\hline
\end{tabular}

From Table 4.8, it can be seen that this equation model has a significance level, that is 0.000 smaller than the level of significance $\alpha(0.05)$ and the result of regression model with ANOVA test or $\mathrm{F}$ test is 11,557 . Therefore, the independent variable in this research model can simultaneously influence the dependent variable that is financial distress. 
Table 8. Result of T Test

\begin{tabular}{llll}
\hline Model & B & t. & Sig. \\
\hline (Constant) & 0.454 & 1.817 & 0.071 \\
\hline Corporate Governance & -0.480 & -1.369 & 0.172 \\
\hline Intellectual Capital & 0.248 & 4.775 & 0.000 \\
\hline
\end{tabular}

Based on the T Test table can be formulized multiple regression analysis:

\section{Financial Distress $=0.454-0.480$ Corporate Governance +0.248 Intellectual Capital}

Based on the results above, statistical tests t shows that of the 2 variables included in the regression model, only intellectual capital variables significantly affect financial distress, because the probability value of significance for intellectual capital is $0,000(p<0.05)$ and has a positive effect of 0.248 . While corporate governance variable has no significant effect on financial distress, because the probability of corporate governance significance is $0.172(\mathrm{p}>$ $0,05)$. So, it can be concluded that financial distress variable is only influenced by intellectual capital variable.

\section{Analysis \\ The Effect of Corporate Governance towards Financial Distress}

The results of this research indicate that corporate governance has insignificant effect towards financial distress. This result is not in line with the research conducted by Huang and Zhao (2008) who mentioned that corporate governance has an influence to the financial distress. However, this insignificant result is still can be explained by the research conducted by Wibowo (2010). Wibowo (2010) stated that companies in Indonesia are unable to implement corporate governance which resulting in inability of these companies to realize the principles of good corporate governance (GCG). According to Wibowo (2010), there are two kinds of obstacles that make companies cannot implement corporate governance, such as internal and external obstacles.

Internal obstacles involves the lack of commitment between board of director (BOD) and the employees within a company to implement corporate governance, the lack of the level of understanding from board of director (BOD) as well as the employees regarding corporate governance, the lack of role models showed by board of director to the employees, the deficiency of company's culture in which supporting the realization of good corporate governance (GCG)'s principle, and the ineffectiveness of internal control system within a company (Djatmiko, 2004 in Wibowo, 2010).

However, external obstacles are departing from the implementation of corporate governance in which related to the set of laws, regulation and law enforcement. According to Wibowo (2010), Indonesia is not lack of laws because the provisions regarding good corporate governance (GCG) are already stated implicitly in corporate's laws, banking regulations, and laws of capital market. However, Wibowo (2010) stated that the law enforcement generated by authority holder such as Bank of Indonesia, Financial Services Authority (OJK), Ministry of Finance, and supreme court are extremely weak. These two obstacles make a company cannot implement the corporate governance.

For the conclusion, researcher concludes that corporate governance has no significant effect towards financial distress because the corporate governance itself is still unable to be implemented in Indonesia as the result of internal and external obstacles. Furthermore, the 
presence or the absence of corporate governance does not affect the financial distress.

\section{The Effect of Intellectual Capital towards Financial Distress}

The statistical result in this research shows that intellectual capital has significant positive influence to the financial distress. However, this significant-influence result can be explained by the previous research conducted by Pour et al. (2014). According to Pour et al. (2014), the increasing of intellectual capital - which is marked by the increasing of staff salary, does not followed by the improvement of productions' efficiency. Instead, the increasing of staff salary is followed by the deficiency of productions' improvement in term of its efficiency. This lack of improvement is indicated by the escalation of production costs and indirectly can increase the debt of a company in order to cover the production costs. This debt however, can also increasing the interest to be paid by a company. For the conclusion, the increasing of intellectual capital followed by the increasing of production costs and debts of a company can subsequently increasing the financial distress of that company.

\section{CONCLUSION}

The objective of this research is to examine the effect of corporate governance and intellectual capital towards financial distress. This research is a quantitative method that used data in the form number and testing using statistical analysis. Data used are secondary data acquired from 83 manufacturing companies listed in IDX 2014-2016. Based on the results of data analysis and discussion, it can be concluded that corporate governance has no significant effect on financial distress and intellectual capital has a significant positive on financial distress. This indicates that the presence or absence of corporate governance in the company has no impact on financial distress. This indicates that the higher the intellectual capital the more likely the occurrence of financial distress. First, the independent variable used in this study only 2 variables with Adjusted $\mathrm{R}^{2}$ only $0.086(8.6 \%)$. So, there are other factors that are more influential on financial distress. Second, the sample is limited to manufacturing companies listed in IDX 2014-2016. Third, the measurement of corporate governance is too subjective. The existence of limitations in this research provides opportunities for future research. It is expected to add money management and debt management variables that may affect the financial distress. Moreovere, future research may use companies in other sectors, such as service companies as the sample and make the period longer, for example 5 years to get more data. Also, measurement of corporate governance variables can be change to another measurement, which is more detailed, for example the frequency of audit committee meetings, competence board of commissioners and audit committee.

\section{REFERENCES}

Almilia, L. S., \& Kristijadi. (2017). Analisis Rasio Keuangan untuk Memprediksi Kondisi Financial Distress Perusahaan Manufaktur yang Terdaftar di Bursa Efek. Journal of Business \& Banking, 7(2),183-120.

Altman, E. I. (1968). Financial Ratios, Discriminant Analysis and the Prediction of Corporate Bankruptcy. The Journal of Finance, 23(4), 589-609. doi:10.2307/2978933

Bontis, N. (1998). Intellectual Capital: An Exploratory Study that Develops Measures and Models. Management Decision, 36(2), 63-76. doi:10.1108/00251749810204142

Brailsford, T. J., Oliver, B. R., \& Pua, L. H. (1999). Theory and Evidence on the Relationship 
Between Ownership Structure and Capital Structure. SSRN Electronic Journal, 7(2), 1225. doi:10.2139/ssrn. 181888

Brigham, E. U., \& Daves, P. R. (2003). Intermediate Financial Management (9th ed.). S.1: Thomson Learning Academic Resource Center.

Brooking, A. (1996). On The Importance of Managing Intangible Assets as Part of Corporate Strategy. Electronic Journal of Knowledge Management, 8(2), 217-224. doi:10.1016/s0024-6301(97)80911-9

Haat, M. H. C., Rahman, R. A., \& Mahenthiran, S. (2008). Corporate Governance, Transparency and Performance of Malaysian Companies. Managerial Auditing Journal, 23(8), 744-778. doi:10.1108/02686900810899518

Chen, X. M., Yang, C., \& Chen,S. (2005). Evolution and Computing Challenges of Distributed GIS. Annals of GIS, 11(1), 61-69. doi:10.1080/10824000509480601

Claessens, S., \& Djankov, S. (1999). Ownership Concentration and Corporate Performance in The Czech Republic. Journal of Comparative Economics, 27(3), 498-513. doi:10.1006/jcec. 1999.1598

Clarke, M., Seng, D., \& Whiting, R. H. (2011). Intellectual Capital and Firm Performance in Australia. Journal of Intellectual Capital, 12(4), 505-530. doi:10.1108/14691931111181706

Dwiridotjahjono, J. (2009). Penerapan Good Corporate Governance: Manfaat dan Tantangan Serta Kesempatan Bagi Perusahaan Publik di Indonesia. Jurnal Administrasi Bisnis, 5(2), 101-112.

Eisenhardt, K., \& Eisenhardt, K. M. (1989). Building Theories from Case Study Research. The Academy of Management Review, 14(4), 532-550. doi:10.4135/9781473915480.n52

Elloumi, F., \& Gueyié, J. (2001). Financial Distress and Corporate Governance: An Empirical Analysis. Corporate Governance: The International Journal of Business in Society, 1(1), 15-23. doi:10.1108/14720700110389548

Fama, E. F., \& Jensen, M. C. (1983). Separation of Ownership and Control. Journal of Law and Economics, 26. doi:10.2139/ssrn.94034

Firer, S., \& Williams,M. S. (2003). Intellectual Capital and Traditional Measures of Corporate Performance. Journal of Intellectual Capital, 4(3), 348-360. doi:10.1108/14691930310487806

Friend, I., \& Lang, L. H. (1988). An Empirical Test of The Impact of Managerial SelfInterest on Corporate Capital Structure. The Journal of Finance, 43(2), 271. doi: $10.2307 / 2328459$

Ghozali, I. (2013). Aplikasi Analisis Multivariate dengan Program IBM SPSS 21. Semarang: Badan Penerbit Universitas Diponegoro.

Harrison, S., \& Sullivan, P. H. (2000). Profiting from Intellectual Capital. Journal of Intellectual Capital. 1(1), 33-46. Doi:10.1108/14691930010324124

Huang, H., \& Zhao, J. (2008). Relationship between Corporate Governance and Financial Distress: An Empirical Study of Distressed Companies in China. International Journal of Management, 25(4).

Iskander, M. R., \& Chamlou, N. (2000). Corporate Governance: A Framework for Implementation. Washington: World Bank Publications.

Jensen, M. C., \& Meckling, W. H. (1976). Theory of The Firm: Managerial Behavior, Agency Costs and Ownership Structure. Journal of Financial Economics, 3(4), 305-360. doi:10.2139/ssrn.94043

Kabir, H., \& Rahman, A. R. (2015). The Role of Corporate Governance in Accounting Discretion: The Case of Goodwill Impairment in Australia. SSRN Electronic Journal. doi: $10.2139 /$ ssrn. 2630581

Kaihatu, T. S. (2015). Good Corporate Governance dan Penerapannya di Indonesia. Jurusan 
Ekonomi Manajemen, 8(81), 1-9.

Kamath, G.B. (2007). The Intellectual Capital Performance of Indian Banking Sector. Journal of Intellectual Capital, 8(1), 96-123.

Kerfai, N., Ghadhab, B. B., \& Malouche, D. (2016). Performance Measurement and Quality Costing in Tunisian Manufacturing Companies. The TQM Journal, 28(4), 588-596. doi:10.1108/tqm-10-2013-0119

Lee, T., \& Yeh, Y. (2004). Corporate Governance and Financial Distress: Evidence from Taiwan. Corporate Governance, 12(3), 378-388. doi:10.1111/j.1467-8683.2004.00379.x

Mustika, R., Felino, F. Y., Surya, F., Ananto, R. P., \& Sari, T. I. (2018). Pengaruh Modal Intelektual terhadap Financial Distress Studi pada Perusahaan Pertambangan dan Manufaktur. Jurnal Ekonomi dan Bisnis, 20(1), 120-130.

Platt, H. D., \& Platt, M. B. (2002). Predicting Corporate Financial Distress: Reflections on Choice-Based Sample Bias. Journal of Economics and Finance, 26(2), 184-199. doi:10.1007/bf02755985

Porter, M. E. (1991). Towards A Dynamic Theory of Strategy. Strategic Management Journal, 12(S2), 95-117. doi:10.1002/smj.4250121008

Pulic, A. (1998). Measuring The Performance of a Knowledge-Based Economy. The Economic Impact of Knowledge, 203-211. doi:10.1016/b978-0-7506-7009-8.50018-5

Roos, J., Roos, G., Dragonetti, N. C., \& Edvinsson, L. (1997). Intellectual Capital: Navigating in The New Business Landscape. Basingstoke: Macmillan.

SahamOK. (2014, January 10). Perusahaan Manufaktur di BEI | Saham Ok. Retrieved December 20, 2017, from https://www.sahamok.com

Samaha, K., Dahawy, K., Hussainey, K., \& Stapleton, P. (2012). The Extent of Corporate Governance Disclosure and Its Determinants in A Developing Market: The Case of Egypt. Advances in Accounting, 28(1), 168-178. doi:10.1016/j.adiac.2011.12.001

Sari, R. A. (2012). Pengaruh Karakteristik Perusahaan terhadap Corporate Social Responsibility Disclosure pada Perusahaan Manufaktur yang Terdaftar di Bursa Efek Indonesia. Jurnal Akuntansi, 1(1), 124-140.

Shah, S. B. (2008). The Impact of Corporate Governance on Financial Distress; Evidence from Pakistan. Journal Business, 1-82.

Shahwan, T. M. (2015). The Effects of Corporate Governance on Financial Performance and Financial Distress: Evidence From Egypt. Corporate Governance: The International Journal of Business in Society, 15(5), 641-662. doi:10.1108/cg-11-2014-0140

Shleifer, A., \& Vishny, R. (1997). The Limits of Arbitrage. The Journal of Finance, 52(1), 35-55. doi:10.3386/w5167

Smedlund, A., \& Pöyhönen, A. (2005). Intellectual Capital Creation in Regions: A Knowledge System Approach. Intellectual Capital for Communities, 227-252. doi:10.1016/b978-0-7506-7773-8.50017-0

Stewart, T. A. (1998). Intellectual Capital: The New Wealth of Organizations. New York: Doubleday Dell Publishing Group, Inc. doi:10.1002/pfi.4140370713

Sutojo, S., \& Aldridge, E. J. (2008). Good Corporate Governance. Tata Kelola Perusahaan yang Sehat. Jakarta: PT Damar Mulia Pustaka.

Tan, H. P., Plowman, D., \& Hancock, P. (2007). Intellectual Capital and Financial Returns of Companies. Journal of Intellectual Capital, 8(1), 76-95. doi:10.1108/14691930710715079

Ulum, I. (2008). Intellectual Capital Performance Sektor Perbankan di Indonesia. Jurnal Akuntansi dan Keuangan, 10(2), 77-84. 


\section{APPENDIX}

\section{Questions Corporate Governance Index (CGI)}

\section{A) Disclosure and Transparency (DC)}

1. Does the firm use one of the Big Four international auditing firms?

2. Does the firm disclose the amount of executives' compensations?

3. Does the firm disclose its governance structures and policies?

B) Board of Directors' Characteristics (BOD)

1. Does the Board have more than 50\% external directors (non-executive directors)?

2. Is there a permanent auditing committee?

3. Does the board contain at least one-third of members as independent members?

4. Are Board Committees chaired by independent members?

5. Do Board Committees consist of at least three non-executive board members the majority of whom are independent?

6. Does the Board contain female members?

C) Shareholder Rights and Investor Relations (SI)

1. Is there an institutional investor with at least $5 \%$ of the firm's equity?

2. Does the firm exercise the one-share one-vote rule indiscriminately?

D) Ownership and Control Structure (OC)

1. Does the firm disclose its ownership structure?

2. Do controlling shareholders hold less than $70 \%$ of voting rights?

3. Does the firm have employee stock options (ESOPs)?

4. Is there an ownership concentration where at least 5 percent of firm's equity ownership is held by an investor? 